\title{
Airway Hyperresponsiveness: An Unsung Clinical Manifestation
}

Rao VD*

Center for Excellence in Genomics, Madurai Kamaraj University, Tamilnadu, India

*Corresponding author: Rao VD, Center for Excellence in Genomics, Madurai Kamaraj University, Tamilnadu, India, Tel: 9963387790; E-mail: vanabt009@gmail.com Received date: May 23, 2016; Accepted date: June 26, 2016; Published date: June 28, 2016

Copyright: @ 2016 Rao VD. This is an open-access article distributed under the terms of the Creative Commons Attribution License, which permits unrestricted use, distribution, and reproduction in any medium, provided the original author and source are credited.

\begin{abstract}
Airway Hyperresponsiveness (AHR) is one of the key features of asthma and chronic obstructive pulmonary disease (COPD), where the airway sensitivity is increased. The research suggested that there is a relation between inflammatory state and severity of hyperresponsiveness of the airway, though the causative agents and consequences are different in asthma and COPD. However, before estimating hyperresponsiveness, there is a need to understand the consequences of airway inflammation, which are different in asthma and COPD. Over the past decades, there was an increased interest in unfold the multidimensional link between airway inflammation and hyperresponsiveness. This raises the hope for the future in development of diagnosis and treatment options for AHR. This short note intends to summarize the clinical correlation between airway inflammation and hyperresponsiveness and the significance of measurement of hyperresponsiveness.
\end{abstract}

Keywords: Airway hyperresponsiveness; Asthma; Airway inflammation; COPD

Abbreviations: AHR: Airway Hyperresponsiveness; COPD: Chronic Obstructive Pulmonary Disease; VEGF: Vascular Endothelial Growth Factor; BHR: Bronchial Hyperreactivity; OVA: Ovalbumin; CKLF 1: Chemokine-like Factor 1; Cav-1: Caveolin-1; ASM: Airway Smooth Muscle.

\section{Airway Hyperresponsivness and Clinical Correlation}

Asthma is a chronic inflammatory disorder, which is associated with airway obstruction and airway hyperresponsiveness. Research over the past decades suggested that there might be a relationship between airway inflammation and hyperresponsiveness. Airway inflammation process affects the central areas of the lung in asthma patients, whereas the peripheral airway wall is affected in CODP. The asthmatic airways are hyperresponsive to the variety of stimuli; therefore, one inflammatory cell may not be a central cause for the pathogenesis [1-3]. To improve the understanding of asthma, AHR has to be categorized into structural and inflammatory changes in the airway wall; therefore, the correlation between AHR and airway inflammation could be measured [4]. Previous studies suggested that there is no strong correlation between AHR and inflammation. In allergic airway disease (asthma), the inflammation and AHR are two independent processes, AHR being derived from independent factors that are modulated by inflammatory factors but not caused by inflammation directly [5]. In another study, it was showed that chronic airway inflammatory factors may be responsible for structural changes in the airway, but there is no interference of airway inflammation measurement in AHR estimation [2]. According to the recent research, it is accepted that there is an "Asthmatic Airway Remodeling", which is associated with AHR. In this airway-remodeling concept, airway is denser than that of normal airway. It is believed that vascular endothelial growth factor (VEGF) expressions are associated with bronchial asthma and AHR. A study reported that there is higher expression levels of sputum VEGF in asthmatic children, which is believed to be a potential pathogenic agent and a biomarker for airway inflammation [6]. Another study by Yllmaz et al. evaluated the relationship between bronchial hyperreactivity (BHR) and VGEF-A in allergic rhinitis patients and reported that BHR is associated with vascular component of remodeling (angiogenesis) [7]. However, in a recent study, Avdalovic et al. reported in rhesus macaque model of asthma that either increased vascular density or expression VEGF are not primary responsible factors for increased AHR [8].

Some reports proved that steroids, expression levels of various cytokines, food supplements such as vitamins, and other causative factors are correlated with airway inflammation and hyperresponsiveness. Kim et al. reported that increased mRNA expressions of IL-13 and IL-25 play a key role in house dust mite mediated skin inflammation [9]. Li et al. reported that expression of IL-25 is increased in asthmatic airway. Furthermore, they reported that budesonide, a steroid medication, reduces type 2 cytokine induced inflammation and prevent AHR [10]. There are evidences suggesting that COPD and asthma might have similar genetic factors, but most of them failed to provide consistent results. A study conducted in a Japanese population reported the role of gene polymorphism of IL-13, IL-17A and mast cell chymase gene (CMA1) and concluded that the genetic variations might have a significant role in COPD and asthma [11]. Mickleborough and Lindley reported the role of fish oil and vitamin $\mathrm{C}$ in airway inflammation and hyperpnea-induced bronchoconstriction. In their study, individuals were tested for combining effect of fish oil and vitamin $\mathrm{C}$, and the conclusion was that the combination does not provide greater anti-inflammatory effects or suppression in bronchoconstriction, whereas individually both are effective [12].

Previously, few studies suggested that various immune system components are associated with airway inflammation and hyperresponsiveness. Mehlhop et al. reported IgE- independent mechanisms correlated with airway inflammation and BHR [13], Grünig et al. reported the role of IL-10 in suppression of Th2-like lung response [14], and Corry et al. reported that CD4+ T cells effectively mediate the pathophysiologic changes that occur in asthma by various mechanisms that are dependent from IL-4 and independent from IL-5, IgE and both [15]. In addition, recent review summarized that 
Page 2 of 3

regulatory $\mathrm{T}$ cells plays a key role in reducing the Th2 cell proliferation by which significantly reduce the airway associated diseases such as asthma [16].

Environmental factors are one of the major causative agents of allergy and asthma. Exposure to different environmental factors has different impact in airway inflammation and hypersensivity. Occupational asthma is one of the most reported airway disorder induced by specific substance within a work place. Brooks conducted a study on irritant-induced asthma and reactive airways dysfunction syndrome and concluded that inhaled steroids are effective in reducing the AHR [17]. Another study by $\mathrm{Wu}$ et al. reported the role of sidestream tobacco smoke in AHR. Comparing the results with their previous studies $[18,19]$ they concluded that exposure to the sidestream tobacco smoking (early postnatal period) can induce acute AHR and airway inflammation, which is considerably significant [20].

\section{Measurement, Diagnosis and Treatment}

There are many models introduced to understand the allergic airway diseases. However, ovalbumin (OVA) in one of them was not effective to all the allergens, since it required an adjuvant for sensitization. To overcome these issues, alternative models such as pollen and fungal derived models were introduced, and the data obtained suggested that there is no need of adjuvant [13-15]. The observations suggested that these allergens are predominant sources of exogenous proteinases and that utilizing these protease depended models provide new insights in the development of new therapeutic strategies for AHR [21-23]. Mindin is an extracellular matrix protein which could effectively modify the severity of the allergic airway diseases after sub-acute exposure to fungal associated proteases. Tighe et al. concluded that mindin could be a bridge between innate and adaptive immune responses [24]. Actually, the understanding of various inducers, suppressors and inhibitors of airway inflammation and hyperresponsiveness may provide new approaches for advanced diagnosis and treatment applications. Over the past decade, research showed that the chemokine-like factor 1 (CKLF 1) is at the center which promotes the inflammatory cell trafficking to inhibit airway inflammation. The discovery and characterization of CKLF 1 is one of the groundbreaking events, which could help in exploring new novel genes for further understanding [25].

Caveolin-1 (cav-1) is another hallmark protein, which is abundantly expressed in the lung and has a great clinical relevance in airway inflammation and AHR. It is important to know how cav-1 is involved in development of lung injury. Unfolding this question may open the doors for the development of next generation therapies for AHR and inflammation [26].

Another issue remains to be investigated to understand the airway diseases such as asthma that concerns the role of phenotypes and their changes. It was believed that eosinophils are predominant in asthma, but also the role of neutrophils in asthma is accepted. It has been proved that the majority of the asthmatic patients are noneosinophilic, whereas a direct correlation was reported between neutrophils and severity of asthma [27-30]. Riesenfeld et al. reported variations of phenotypes of AHR in mouse models and believed that a better in understanding of asthma in humans is needed as well. Indeed, further studies on high numbers of patients are warranted to meet such need [30].

Measurement of airway responsiveness helps in developing safe, quick and reproducible diagnostic methods for asthma. The degree of airway responsiveness could be assessed by employing several tests that are either direct or indirect depending on the activation of airway smooth muscle (ASM). Direct tests stimulate the airway smooth muscle via surface receptors, whereas in indirect tests ASM is activated via mediators released by the host cell $[31,32]$.

\section{Conclusion}

Asthma and related clinical complications such as AHR and airway inflammation are very common since the availability of causative agents. On the other hand, AHR is complex because many cells, tissues and molecules are involved and it is difficult to find out the predominant candidates. Therefore, developing new diagnostic and treatment approaches is complicated. As discussed above, there are many individual systems involved in AHR, this might be one of the major reasons for unfolding the disease so far. However, genomic studies, translational approaches and bioinformatics tools may improve the clinical understanding of AHR, thereby, important novel therapeutic targets, biomarkers and treatment methods could be provided for airways diseases.

\section{References}

1. Holgate ST (1993) Mediators and cytokine mechanisms in asthma. Thorax 48:103-109.

2. Brusasco V, Crimi E, Pellegrino R (1998) Airway hyperresponsiveness in asthma: not just a matter of airway inflammation. Thorax 53: 992-998.

3. Postma DS, Kerstjens HA (1998) Characteristics of Airway Hyperresponsiveness in Asthma and Chronic Obstructive Pulmonary Disease. Am J Respir Crit Care Med 158: 187-192.

4. Busse WW (2010) The Relationship of Airway Hyperresponsiveness and Airway Inflammation. Chest 138: 4-10.

5. Janssen-Heininger YMW, Irvin CG, Scheller EV, Brown AL, Kolls JK, et al. (2012) Airway Hyperresponsiveness and Inflammation: Causation, Correlation, or No Relation? J Aller Ther S1: 008.

6. Hossny E, El-Awady H, Bakr S, Labib A (2009) Vascular endothelial growth factor overexpression in induced sputum of children with bronchial asthma. Pediatr Allergy Immunol 20: 89-96.

7. Yılmaz I, Bayraktar N, Ceyhan K, Seçil D, Yüksel S, et al. (2013) Evaluation of vascular endothelial growth factor A and endostatin levels in induced sputum and relationship to bronchial hyperreactivity in patients with seasonal allergic rhinitis. Am J Rhinol Allergy 27: 181-186.

8. Avdalovic M, Weiss E, Sylvia C, Quesenberry S, Tyler N, et al. (2013) Airway Vascularity is not Associated with Airway Hyper-responsiveness in a Non-human Primate Model of Asthma. J Allergy Ther 4: 149.

9. Kim JY, Jeong MS, Park KY, Seo SJ (2013) Aggravation of atopic dermatitis-like symptoms by consecutive low concentration of formaldehyde exposure in NC/Nga mice. Exp Dermatol 22: 219-221.

10. Li HJ, Liu F, Lu DG, Song YH, Wang C, et al. (2013) IL-25 Involved in Airway Inflammation of OVA-Induced Asthmatic Mice and the Inhibitory Effect of Glucocorticoid. J Allergy Ther 4: 151.

11. Kurosawa M, Sutoh E, Sutoh Y (2015) Interleukin (IL)-13, IL-17A, and Mast Cell Chymase Gene Polymorphisms in Bronchial Asthma and Chronic Obstructive Pulmonary Disease - A Pilot Study in a Japanese Population. J Allergy Ther 6: 224 .

12. Mickleborough TD, Lindley MR (2014) The Effect of Combining Fish Oil and Vitamin $\mathrm{C}$ on Airway Inflammation and Hyperpnea-Induced Bronchoconstriction in Asthma. J Allergy Ther 5: 184.

13. Mehlhop PD, van de Rijn M, Goldberg AB, Brewer JP, Kurup VP, et al. (1997) Allergen-induced bronchial hyperreactivity and eosinophilic inflammation occur in the absence of IgE in a mouse model of asthma. Proc Natl Acad Sci U S A 94: 1344-1349.

14. Grünig G, Corry DB, Leach MW, Seymour BW, Kurup VP, et al. (1997) Interleukin-10 is a natural suppressor of cytokine production and 
inflammation in a murine model of allergic bronchopulmonary aspergillosis. J Exp Med 185: 1089-1099.

15. Corry DB, Grünig G, Hadeiba H, Kurup VP, Warnock ML, et al. (1998) Requirements for allergen-induced airway hyperreactivity in $\mathrm{T}$ and $\mathrm{B}$ cell-deficient mice.Mol Med 4: 344-355.

16. Lowder TW, Kunz HE (2011) Regulatory T Cells in Asthma and Airway Hyperresponsiveness. J Aller Ther S1: 002.

17. Brooks SM (2014) Irritant-Induced Asthma and Reactive Airways Dysfunction Syndrome (RADS). J Allergy Ther 5: 174.

18. Wu ZX, Lee LY (1999) Airway hyperresponsiveness induced by chronic exposure to cigarette smoke in guinea pigs: role of tachykinins. J App Physiol87: 1621-1628.

19. Wu ZX, Hunter DD, Kish VL, Benders KM, Batchelor TP, et al. (2009) Prenatal and early, but not late, postnatal exposure of mice to sidestream tobacco smoke increases airway hyperresponsiveness later in life. EnvironHealth Perspect 117: 1434-1440.

20. Wu ZX, Hunter DD, Batchelor TP, Dey RD (2013) Exposure to Sidestream Tobacco Smoke Induces Airway Hyperresponsiveness and Inflammation in Early Postnatal Mice. J Allergy Ther 4: 153.

21. Kheradmand F, Kiss A, Xu J, Lee SH, Kolattukudy PE, et al. (2002) A proteaseactivated pathway underlying Th cell type 2 activation and allergic lung disease. J Immunol 169: 5904-5911.

22. Voehringer D, Shinkai K, Locksley RM (2004) Type 2 immunity reflects orchestrated recruitment of cells committed to IL-4 production. Immunity 20: 267-277.

23. Lim KC, Sun E, Bahgat M, Bucks D, Guy R, et al. (1999) Blockage of skin invasion by schistosome cercariae by serine protease inhibitors. Am J Trop Med Hyg 60: 487-492.
24. Tighe RM, Potts EN, Feng F, Li Z, Frush B, et al. (2011) Extracellular Matrix Protein Mindin is Required for the Complete Allergic Response to Fungal-Associated Proteinase. J Aller Ther S1: 001.

25. Tan YX, (2012) Progress in Chemokine-Like Factor 1 Research over the Past 10 Years: From Promoting Inflammatory Cell Trafficking to Inhibiting Allergic Airway Inflammation. J Aller Ther S1: 006.

26. Hsia BJ, Pastva AM, Giamberardino CD, Potts-Kant EN, Foster WM, et al. (2012) Increased Nitric Oxide Production Prevents Airway Hyperresponsiveness in Caveolin-1 Deficient Mice Following Endotoxin Exposure. J Aller Ther S1: 004.

27. Bousquet J, Chanez P, Lacoste JY, Barneon G, Ghavanian N, et al. (1990) Eosinophilic inflammation in asthma. N Engl J Med 323: 1033-1039.

28. Wardlaw AJ, Brightling C, Green R, Woltmann G, Pavord I (2000) Eosinophils in asthma and other allergic diseases. Br Med Bull 56: 985-1003.

29. Fahy JV, Kim KW, Liu J, Boushey HA (1995) Prominent neutrophilic inflammation in sputum from subjects with asthma exacerbation. J Allergy Clin Immunol 95: 843-852.

30. Riesenfeld E, Allen GB, Bates JHT, Poynter ME, Wu M, et al. (2012) The Temporal Evolution of Airways Hyperresponsiveness and Inflammation. J Aller Ther S1: 005.

31. O'Byrne PM, Inman MD (2003) Airway hyperresponsiveness.Chest 123 : $411-416$.

32. Bossé Y, Lee-Gosselin A, Boulet LP, King GG (2013) Airway Hyperresponsiveness in Asthma: A Better Understanding Yet to Yield Clinical Benefit. J Allergy Ther 4: 150. 